\title{
PENGARUH PERENCANAAN PAJAK DAN PROFITABILITAS TERHADAP MANAJEMEN LABA PADA PERUSAHAAN MANUFAKTUR SUB SEKTOR TEKSTIL DAN GARMEN YANG TERDAFTAR DI BURSA EFEK INDONESIA TAHUN 2014 - 2017
}

\author{
Luhgiatno ${ }^{1}$ \\ Andri Novius $^{2}$ \\ Dosen Tetap STIE Pelita Nusantara Semarang ${ }^{1}$ \\ Dosen Tetap Fakultas Ekonomi UIN Sultan Syarif Kasim Riau ${ }^{2}$
}

Diterima: Agustus 2019, Disetujui: September 2019, Dipublikasikan: Oktober 2019

\begin{abstract}
This study aims to examine empirical evidence to what extent the influence of tax planning, profitability, on earnings management. The research method uses quantitative methods. The population of this study was textile and garment companies that were listed on the Indonesia Stock Exchange in 2014-2017. Sample selection using purposive sampling method. A sample of 10 companies with four years of observation, so that the total test sample was 40 observations. The type of data uses secondary data, analysis of data using the classical assumption test and hypothesis testing using panel data regression analysis (pooled data) using Eviews 9 software.

The results of this study indicate that the hypothesis is partially namely tax planning does not significantly influence earnings management while profitability has a significant effect on earnings management. For the results of testing simultaneously between tax planning, profitability, has a significant effect on earnings management. From the results of this study also obtained the Determination Coefficient (R2) with a value of 0.517199 means that $51.71 \%$ of the disclosure is explained by the Tax Planning variable and Profitability.
\end{abstract}

Keywords: Tax Planning, Profitability, Earning Management

\begin{abstract}
Abstrak
Penelitian ini bertujuan untuk menguji bukti empiris sejauh mana pengaruh perencanaan pajak, profitabilitas, terhadap manajemen laba. Metode penelitian menggunakan metode kuantitatif. Populasi penelitian ini perusahaan tekstil dan garmen yang terdaftar di Bursa Efek Indonesia pada tahun 2014-2017. Pemilihan sampel dengan metode purposive sampling. Sampel sebanyak 10 perusahaan dengan empat tahun pengamatan, sehingga total sampel pengujian adalah 40 observasi. Jenis data menggunakan data sekunder, analisis data menggunakan uji asumsi klasik dan pengujian hipotesis menggunakan analisis regresi data panel (pooled data) menggunakan alat bantu Eviews 9.

Hasil penelitian ini menunjukkan bahwa hipotesis secara parsial yaitu perencanaan pajak tidak berpengaruh secara signifikan terhadap manajemen laba sedangkan profitabilitas berpengaruh signifikan terhadap manajemen laba. Untuk hasil pengujian secara simultan antara perencanaan pajak, profitabilitas, berpengaruh
\end{abstract}


secara signifikan terhadap manajemen laba. Dari hasil penelitian ini juga diperoleh Koefisien Determinasi $\left(R^{2}\right)$ dengan nilai 0.517199 memiliki arti bahwa sebesar $51,71 \%$ pengungkapan dijelaskan oleh variabel Perencanaan Pajak dan Profitabilitas.

Kata Kunci: Perencanaan Pajak, Profitabilitas, Manajemen Laba

\section{PENDAHULUAN \\ Latar Belakang}

Salah satu informasi yang terdapat dalam laporan keuangan adalah laba perusahaan. Laba adalah selisih antara jumlah yang diterima dari pelanggan atas barang atau jasa yang dihasilkan dengan jumlah yang dikeluarkan untuk membeli sumber daya alam ataupun pengeluaran lainnya dalam menghasilkan barang atau jasa tersebut. Setiap perusahaan akan melakukan berbagai upaya yang dapat digunakan untuk mendapatkan laba yang tinggi. Salah satu upaya yang dilakukan oleh perusahaan adalah dengan melakukan manajemen laba untuk menutupi kekurangan yang terdapat pada salah satu elemen kinerja perusahaan (Hasni,2013). Manajemen laba adalah suatu langkah dimana manajer melakukan intervensi dalam penyusunan laporan keuangan yang bertujuan untuk merekayasa laporan keuangan tersebut dengan maksud untuk menguntungkan dirinya sendiri atau menguntungkan perusahaan. Hal ini dikarenakan bonus yang akan diperoleh manajemen, dimana semakin tinggi laba yang diperoleh maka akan semakin tinggi pula bonus yang akan diberikan perusahaan kepada pihak manajemen yang mengelola perusahaan sercara langsung. Oleh sebab itu pihak manajemen perusahaan berusaha untuk memberikan signal positif kepada pasar tentang perusahaan yang dikelolanya dan menaikkan laba yang dilaporkan kepada para pemegang saham dan pengguna eksternal lainnya.

Tindakan manajemen memanipulasi informasi keuangan dengan melaporkan laba yang dinaikkan mengindikasikan adanya praktik manajemen laba pada perusahaan. Manajemen laba dilakukan oleh manajer dengan menggunakan penilaian tertentu dalam pelaporan keuangan dan menyusun transaksi untuk mengubah laporan keuangan guna menyesatkan stakeholders mengenai kinerja ekonomi yang terjadi. Konsep mengenai manajemen laba dapat dijelaskan dengan menggunakan pendekatan teori keagenan (agency theory). Teori tersebut menyatakan bahwa praktik manajemen laba dipengaruhi konflik kepentingan antara pihak yang berkepintingan (principal) dengan manajemen sebagai pihak yang menjalankan kepentingan atau agen. Konflik ini muncul pada setiap pihak berusaha untuk mencapai tingkat kemakmuran yang diinginkan.

Adanya fleksibilitas dalam standar akuntansi memungkinkan manajer dalam penggunaan akuntansi akrual. Dengan menggunakan fleksibilitas yang diperbolehkan oleh standar akuntansi, manajemen dapat melakukan tindakan manajemen laba dengan menggunakan disecretionary accrual (kebijakan akrual yang berada dibawah kebijakan manajemen) dimaksudkan untuk menjadikan laporan keuangan lebih informatif, yaitu laporan keuangan yang dapat mencerminkan keadaan yang sesungguhnya. Tetapi kenyataannya, discretionary accrual ini telah disalahgunakan oleh manajemen, sehingga dapat dimanfaatkan untuk menyusun laporan keuangan dalam rangka menaikkan atau menurunkan laba. Ada tiga motivasi utama yang mempengaruhi perusahaan melakukan manajemen laba yaitu menghindari penurunan laba, menghindari 
kerugian dan kegagalan yang dibuat analis. Oleh karena itu, pendeteksian terhadap indikasi manajemen laba pada laporan keuangan menjadi perlu untuk dilakukan.

Pada umumnya manajemen laba dilakukan untuk memaksimumkan laba agar dapat memenuhi berbagai kepentingan termasuk dalam menghimpun dana melalui hutang. Jadi manajemen akan cenderung melakukan manajemen laba ketika laba yang diperoleh lebih rendah dari target. Perusahaan yang besar dan memiliki return yang tinggi akan lebih melakukan manajemen laba juga karena perusahaan yang besar pastinya akan memerlukan dana yang besar pula untuk rencana pengembangan perusahaan untuk waktu kedepannya.

Sedangkan, dampak utama dari manajemen laba adalah menurunnya kualitas laporan keuangan. Manajemen laba merupakan salah satu faktor yang dapat mengurangi kredibilitas laporan keuangan dan menambah bias dalam laporan keuangan serta dapat mengganggu pemakai laporan keuangan yang mempercayai angka laba hasil rekayasa tersebut sebagai angka laba tanpa rekayasa.

Kasus kecurangan praktik manajemen laba telah banyak terjadi di Indonesia dan dunia Internasional. Contoh praktik manajemen laba didunia Internasional yaitu peruahaan terkemuka di Amerika Enron dan Worldcom sepanjang tahun 2002 bermula dari kecurangan merekayasa laporan keuangan yang menyesatkan dan membingungkan pada laporan laba/rugi perusahaan yang otomatis mempengaruhi harga saham yang mengakibatkan kepercayaan terhadap perusahaan menurun dan akhirnya bangkrut (www.unisosdem.org).

Sedangkan contoh kasus praktik manajemen laba pada perusahaan di Indonesia yaitu kasus PT.Katarina Utama juga melakukan pemalsuan laporan keangan pada tahun 2009 dan PT.Kimia Farma Tbk merupakan produsen obat-obatan milik pemerintah Indonesia salah satu perusahaan Manufaktur yang terdaftar di BEI. Praktik manajemen laba yang dilakukan akuntan dalam kasus PT. Kimia Farma Tbk (PTKAEF) pada tahun 2002 dengan memanipulasi laporan keuangan dengan menaikkan laba hingga 31,7 Miliar, praktik manajemen laba tersebut diduga terkait keinginan manajemen lama untuk terpilih kembali mengelola perusahaan farmasi tersebut (Bapepam : 2002).

Kasus serupa juga terjadi PT. Great River yang bergerak dibidang pembuatan pakaian. Kasus tersebut terjadi pada tahun 2006, auditor investigasi Aryanto, Amir, dan Mawar menemukan indikasi penggelembungan akun penjualan, piutang dan asset hingga ratusan miliar rupiah di PT. Great River (Bapepam:2007).

Penelitian ini difokuskan pada sektor tekstil dan garmen sehubungan dengan adanya krisis keuangan global pada tahun 2008. Industri tekstil dan garmen adalah industri yang bergerak dari dalam negeri maupun luar negeri yang mampu menyerap sekitar 500.000 tenaga kerja, sehingga sangat berperan penting. Seperti yang dikemukakan oleh Mahalia Adanya pemberitahuan mengenai dampak krisis keuangan global pada tahun 2008 di media massa terhadap sektor industri di bidang manufaktur. Dengan kondisi seperti ini para manajer cenderung melakukan manajemen laba dengan membuat laporan keuangan agar terlihat baik, maka para investor tetap ingin menanamkan kepemilikannya di perusahaan tersebut.

Penelitian ini menggunakan sampel perusahaan sub sektor Tekstil dan Garmen yang terdaftar di Bursa Efek Indonesia berdasarkan kasus keuangan global yang terjadi pada tahun 2008. Adapun variabel penelitian yang digunakan adalah: Perencanaan Pajak dan Profitabilitas (sebagai variabel independen), dan Manajemen Laba (sebagai variabel dependen). 


\section{Rumusan Masalah} sebagai berikut:

Berdasarkan penjelasan diatas, rumusan masalah dalam penelitian ini adalah

1. Apakah Perencanaan Pajak, Profitabilitas, berpengaruh secara parsial terhadap Manajemen Laba pada perusahaan manufaktur sub sektor tekstil dan garmen yang terdaftar di Bursa Efek Indonesia?

2. Apakah Perencanaan Pajak, Profitabilitas berpengaruh secara simultan terhadap Manajemen Laba pada perusahaan manufaktur sub sektor tekstil dan garmen yang terdaftar di Bursa Efek Indonesia?

\section{Tujuan dan Manfaat Penelitian}

\section{Tujuan Penelitian}

Berdasarkan perumusan masalah diatas, maka tujuan yang hendak dicapai dalam penelitian ini adalah:

1. Untuk mengetahui apakah terdapat pengaruh secara parsial Perencanaan Pajak dan Profitabilitas terhadap Manajemen Laba pada perusahaan manufaktur sub sektor tekstil dan garmen yang terdaftar di Bursa Efek Indonesia tahun 20142017.

2. Untuk mengetahui apakah perencanaan pajak dan profitabilitas, berpengaruh secara simultan terhadap manajemen laba pada perusahaan manufaktur sub sektor tekstil dan garmen yang terdaftar di Bursa Efek Indonesia?

\section{Manfaat Penelitian}

Adapun manfaat yang diharapkan dari penelitian ini adalah sebagai berikut:

1. Bagi penulis

Penelitian ini diharapkan dapat mengubah dan menambah pengetahuan dan wawasan dalam bidang manajemen laba khususnya.

2. Bagi investor

Mengingat kemungkinan terjadinya praktik manajemen laba pada perusahaan maka penelitian ini diharapkan dapat mencapai acuan investor dalam mengambil keputusan.

3. Bagi perusahaan

Dengan adanya penelitian ini diharapkan perusahaan dapat membuat laporan keuangan sesuai dengan ketentuan yang berlaku, sehingga informasi yang diberikan perusahaan tidak menyesatkan dalam pengambilan keputusan bagi pihak-pihak yang berkepentingan. 


\section{Bagi Civitas Akademik}

Penelitian ini diharapkan mampu memberikan kontribusi konseptual bagi pengembangan literature tentang manajemen laba sehingga dapat dijadikan bahan rujukan dalam penelitian selanjutnya.

\section{LANDASAN TEORI}

\section{Teori Agenci (Agency Theory)}

Teori keagenan atau agency theory merupakan gambaran hubungan antara pihak yang memiliki wewenang yakni investor yang juga biasa disebut dengan principal dengan para manajer yang merupakan agent yang diberikan wewenang. Teori keagenan tersebut juga dapat dilihat sebagai suatu model kontraktual antar dua atau lebih pihak, yaitu dimana salah satu pihak disebut agent dan pihak lain disebut principal. Wolk et al (1999) dalam Astuti (2011:13) menyebutkan bahwa dalam teori keagenan perusahaan merupakan titik temu hubungan keagenan antara pemilik perusahaan (principal) dengan manajemen (agent), dengan masing-masing pihak yang terlibat dalam hubungan keagenan tersebut berusaha untuk memaksimalkan utilitas mereka.

Teori keagenan menyatakan bahwa praktik manajemen laba dipengaruhi oleh adanya konflik kepentingan antara agentdan principal yang timbul ketika setiap pihak berusaha untuk mencapai atau mempertahankan tingkat kemakmuran yang dikehendakinya (Djamaluddin, 2008:56). Principal tidak memiliki informasi yang cukup mengenai kinerja agent, maka principal tidak pernah merasa pasti bagaimana usaha agen memberikan kontribusi pada hasil aktual perusahaan.Dengan demikian, principal berada sebagai asimetri informasi karena agent lebih mengetahui kinerja dan aktivitas perusahaan dibandingkan principal.

\section{Manajemen Laba \\ Pengertian Manajemen Laba}

Manajemen laba adalah pilihan yang dilakukan manajer dalam menentukan kebijakan akuntansi, atau aksi nyata yang mempengaruhi laba sehingga mencapai sasaran dengan melaporkan laba tertentu.

Scott (2015) membagi manajemen laba yang mungkin dilakukan oleh para manajer perusahaan kedalam empat jenis pola manajemen laba, yaitu:

\section{a. Taking a bath}

Manajemen mencoba mengalihkan expexted future cost ke masa kini, agar memiliki peluang yang lebih besar mendapatkan laba dimasa yang akan datang. Biasanya dilakukan jika perusahaan mengadakan restrukturisasi atau reorganisasi seperti pergantian CEO.

b. Income minimization

Manajemen mencoba memindahkan beban ke masa kini agar memiliki peluang yang lebih besar mendapatkan laba di masa mendatang.

c. Income maximization

Manajemen mencoba meningkatkan laba masa kini dengan memindahkan ke masa yang akan datang. Biasanya dilakukan oleh manajer dalam rangka memperoleh bonus tahunan. 


\section{d. Income smoothing}

Tindakan dimana manajemen memperhalus fluktuasi laba dari periodeke periode dengan cara memindahkan laba periode yang memiliki laba tinggi ke periode yang memiliki laba rendah.

\section{Motivasi Manajemen Laba}

Sulistiawan (2011:31-37) mengatakan bahwa terdapat beberapa hal yang menjadi motivasi perusahaan melakukan manajemen laba, yaitu:

a. Motivasi Bonus

Dalam sebuah perjanjian bisnis, pemegang saham akan memberikan sejumlah insentif dan bonus sebagai feedback atau evaluasi atas kinerja manajer dalam menjalankan operasional perusahaan. Insentif ini diberikan dalam jumlah relatif tetap dan rutin.

b. Motivasi utang

Selain melakukan kontrak bisnis dengan pemegang saham, untuk kepentingan ekspansi perusahaan, menajer seringkali melakukan beberapa kontrak bisnis dengan pihak ketiga, dalam hal ini adalah kreditor. Agar kreditor mampu menginvestasikan dana diperusahaannya. Selain itu, untuk memperoleh hasil maksimal yaitu pinjaman dengan jumlah yang besar manajer mengelola laba untuk menampilkan performa yang baik.

c. Motivasi pajak

Tindakan manajemen laba tidak hanya terjadi pada perusahaan go public dan selalu untuk kepentingan harga saham, tetapi juga untuk kepentingan perpajakan. Kepentingan ini didominasi oleh perusahaan yang belum go public.

d. Motivasi penjualan saham

Motivasi ini banyak oleh perusahaan yang akango public ataupun sudah go public. Perusahaan yang akango public akan melakukan penawaran saham perdananya ke publik atau lebih dikenal dengan istilah Initial Public Offerings (IPO) untuk memperoleh tambahan modal usaha dari calon investor.

e. Motivasi penggantian direksi

Manajemen laba biasanya terjadi pada sekitar periode pergantian direksi atau CEO, menjelang berakhirnya jabatan, direksi cenderung bertindak memaksimalkan laba agar performa kinerjanya tetap terlihat baik pada tahun terakhir ia menjabat.

f. Motivasi politisi

Motivasi ini biasanya terjadi pada perusahaan besar yang bidang usahanya banyak menyentuh masyarakat luas.Perusahaan cenderung menjaga posisi keuangannya dalam keadaan tertentu sehingga prestasi atau kinerjanya tidak terlalu baik.Jadi, pada aspek politis ini manajer cenderung melakukan mengelola laba untuk menyajikan laba yang lebih rendah dari nilai yang sebenarnya, terutama selama periode kemakmuran tinggi. 


\section{Teknik Manajemen Laba}

Teknik manajemen laba menurut Dhamayanti (2008) adalah sebagai berikut:

a. Perubahan Metode Akuntansi

Mengubah metode akuntansi yang berbeda dengan metode yang sebelumnya sehingga dapat menaikkan atau menurunkan angka laba. Misalnya: mengubah metode depresiasi garis lurus dan merubah metode penilaian persediaan dan metode LIFO ke metode FIFO atau sebaliknya.

b. Menaikkan Kebijakan Perkiraan Akuntansi

Manajemen mempengaruhi laporan keuangan dengan cara memainkan kebijakan perkiraan akuntansi. Misalnya: kebijakan mengenai perkiraan jumlah piutang tidak tertagih dan kebijakan mengenai perkiraan umur aktiva tetap berwujud dan tidak berwujud.

c. Menggeser Periode Biaya atau Pendapatan

Menggeser periode biaya atau pendapatan sering juga disebut sebagai manipulasi keputusan operasional.Misalnya mempercepat atau menunda pengeluaran promosi sampai periode akuntansi berikutnya, mempercepat atau menunda pengiriman produk kepelanggan.

\section{Pajak}

\section{Pengertian Pajak}

Pajak menurut pasal 1 UU No.28 tahun 2007 tentang ketentuan umum dari tata cara perpajakan adalah "kontribusi wajib pajak kepada Negara yang terutang oleh orang pribadi atau badan yang bersifat memaksa berdasarkan undang-undang dengan tidak mendapatkan timbal balik secara langsung dan digunakan untuk keperluan Negara bagi sebesar-besarnya kemakmuran rakyat.

\section{Perencanaan Pajak}

Secara garis besar pengertian perencanaan pajak (tax planning) menurut Mohammad Zain dalam bukunya Manajemen perpajakan (2005:43) menyebutkan bahwa "Perencanaan Pajak (tax planning) adalah proses mengorganisasikan usaha wajib pajak atau sekelompok wajib pajak sedemikian rupa sehingga utang pajaknya, baik pajak penghasilan maupun pajak lainnya, berada dalam posisi yang paling minimal, sepanjang hal ini dimungkinkan oleh ketentuan peraturan perundangundangan perpajakan". Perencanaan pajak merupakan langkah awal dalam melakukan manajemen pajak. Pada tahap ini dilakukan pengumpulan dan penelitian terhadap peraturan perpajakan agar dapat diseleksi jenis tindakan dan penghematan pajak yang akan dilakukan. Pohan (2013) mendefenisikan perencanaan pajak sebagai mengorganisasi usaha wajib pajak orang pribadi maupun badan usaha sedemikian rupa dengan memanfaatkan berbagai celah kemungkinan yang dapat ditempuh oleh perusahaan dalam koridor ketentuan peraturan perpajakan (loopholes), agar perusahaan dapat membayar pajak dalam jumlah minimum. Tujuan perencanaan pajak adalah merekayasa agar beban pajak dapat ditekan serendah mungkin dengan memanfaatkan peraturan yang ada. 


\section{Profitabilitas}

Profitabilitas adalah kemampuan perusahaan dalam memperoleh laba di mana masing-masing pengukuran dihubungkan dengan volume penjualan, total aktiva maupun modal sendiri (Lukman, 2009:59). Tingkat profitabilitas yang tinggi menunjukkan bahwa kinerja perusahaan baik dan pengawasan berjalan dengan baik, sedangkan dengan tingkat profitabilitas yang rendah menunjukkan bahwa kinerja perusahaan kurang baik, dan kinerja manajemen tampak buruk di mata principal (Indri, 2011:37).

\section{Kerangka Pemikiran}

Untuk lebih menjelaskan hubungan antar variabel Independen dan variabel Dependen yang digunakan dalam penelitian ini, berikut digambarkan secara menyeluruh tentang Pengaruh Perencanaan Pajak dan Profitabilitas Terhadap Manajemen Laba Pada Perusahaan Manufaktur Sub Sektor Tekstil dan Garmen yang terdaftar di Bursa Efek Indonesia yang merupakan kerangka konseptual dalam penelitian ini adalah sebagai berikut:

\section{Gambar 1 \\ Kerangka Pemikiran \\ Variabel Independen}

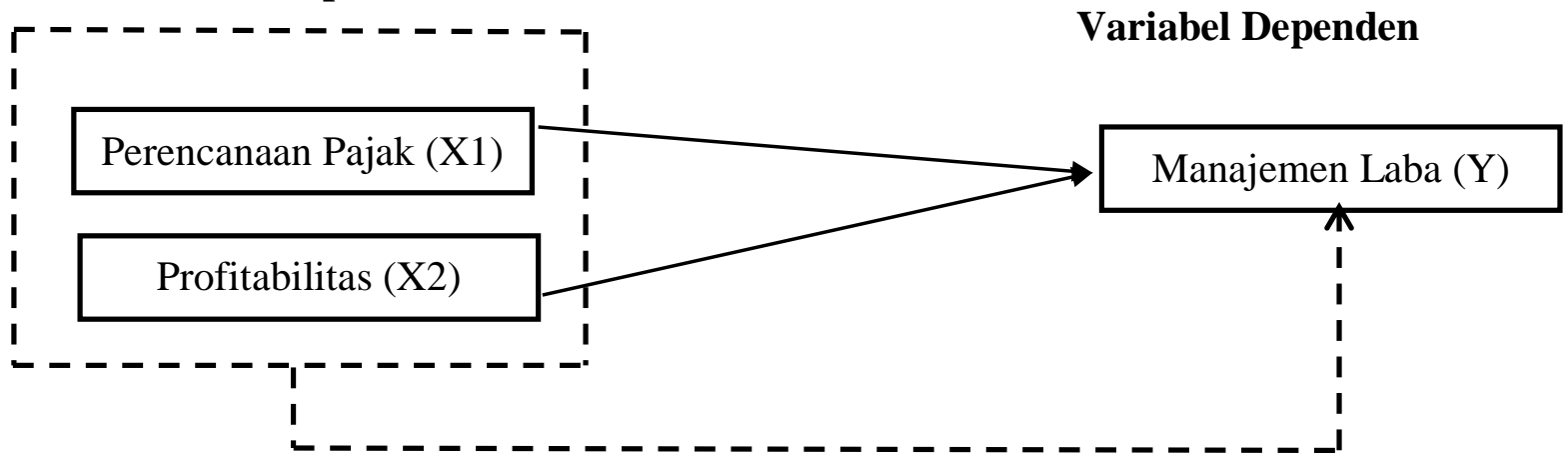

Keterangan:

$\rightarrow$ : Secara Parsial

$\rightarrow$ : Secara Simultan

\section{Pengembangan Hipotesis}

\section{Pengaruh Perencanaann Pajak Terhadap Manajemen Laba}

Perencanaan pajak merupakan suatu proses mengorganisasikan usaha wajib pajak sedemikian rupa agar utang pajak nya baik pajak penghasilan maupun pajak lainnya berada dalam jumlah minimal selama hal tersebut tidak melanggar ketentuan undang-undang (Pohan, 2016). Oleh karena itu tentunya untuk mendukung asumsi diatas diperlukannya sumber data yang berhubungan dengan laporan keuangan sehingga dapat mengatur cash flow perusahaan seefektif mungkin dengan tetap memperhatikan ketentuan perpajakan. 
Penelitian yang dilakukan Ulfa (2012) menunjukan bahwa perencanaan pajak memiliki pengaruh positif, semakin tinggi perencanaan pajak maka semakin besar peluang perusahaan melakukan manajemen laba.

Dari uraian tersebut maka hipotesis pertama yang dapat diajukan sebagai penelitian ini adalah:

H1: Perencanaan pajak berpengaruh terhadap manajemen laba.

\section{Pengaruh Profitabilitas Terhadap Manajemen Laba}

Profitabilitas merupakan suatu indikator kinerja manajemen dalam mengelola kekayaan perusahaan.Profitabilitas menunjukkan kemampuan manajemen dalam menghasilkan laba dengan memanfaatkan aktiva yang digunakan dalam kegiatan operasi. Perusahaan yang memperoleh laba yang besar akan tetap mempertahankan labanya karena untuk memberikan dampak kepercayaan terhadap investor agar mau berinvestasi pada perusahaan yang dikelolanya. Guna dan Herawaty (2010) menyatakan bahwa profitabilitas berpengaruh positif terhadap manajemen laba. Berdasarkan uraian diatas, maka hipotesis ke 2 yang diajukan adalah sebagai berikut:

$\mathrm{H} 2$ : Profitabilitas berpengaruh terhadap manajemen laba

\section{Pengaruh Perencanaan Pajak, Profitabilitas terhadap Manajemen Laba}

Selain meneliti faktor-faktor yang mempengaruhi manajemen laba diatas secara parsial penelitian ini juga mencoba untuk mengetahui pengaruh faktor-faktor diatas secara simultan yaitu bahwa pengaruh perencanaan pajak, profitabilitas terhadap manajemen laba. Untuk itu ditarik hipotesis sebagai berikut:

H3: Perencanaan Pajak, Profitabilitas, berpengaruh terhadap Manajemen Laba

\section{METODE PENELITIAN}

\section{Jenis dan Sumber Data}

Jenis dan sumber data yang digunakan dalam penelitian ini menggunakan jenis dan sumber data sekunder. Data sekunder merupakan sumber data penelitian yang diperoleh peneliti secara tidak langsung melalui media perantara (diperoleh dan dicatat oleh orang lain). Data sekunder umumnya berupa bukti, catatan dan laporan historis yang telah tersusun dalam arsip (data dokumenter) yang dipublikasikan dan yang tidak dipublikasikan.

Data sekunder yang digunakan berupa laporan keuangan perusahaan manufaktur yang go publik yang tedaftar di BEI pada tahun 2014-2017 yang telah dipublikasikan. Data tersebut dari www.idx.co.id. Pemilihan BEI sebagai sumber data dengan alasan BEI merupakan bursa efek terbesar dan representative di Indonesia, dimana dalam 2014 hingga 2017 dianggap cukup mewakili kondisi BEI yang relatif normal.

\subsection{Populasi dan Sampel Penelitian}

Populasi penelitian ini adalah perusahaan manufaktur sub sektor tekstil dan garmen yang terdaftar di Bursa Efek Indonesia selama periode 2014-2017. Metode pengambilan sampel yang digunakan adalah purposive sampling. Metode purposive sampling adalah teknik pengumpulan data atas dasar strategi kecakapan atau pertimbangan tertentu. 


\section{Tabel 1}

Proses Pemilihan Sampel

\begin{tabular}{|l|l|l|}
\hline No & Keterangan & Jumlah \\
\hline 1 & $\begin{array}{l}\text { Perusahaan tekstil dan garmen yang terdaftar di } \\
\text { Bursa Efek Indonesi pada tahun 2014-2017 }\end{array}$ & 20 \\
\hline 2 & $\begin{array}{l}\text { Perusahaan tekstil dan garmen yang tidak } \\
\text { mempunyai laporan keuangan lengkap dan tidak } \\
\text { dipubikasikan pada tahun 2014-2017 (ADMG, } \\
\text { MYTX, CNTX, SRIL, SSTM, TFCO, UNIT) }\end{array}$ & 7 \\
\hline 3 & $\begin{array}{l}\text { Perusahaan tekstil dan garmen yang didelisting, } \\
\text { karena tidak memiliki keberlangsungan usaha } \\
\text { (PAFI, UNTX) }\end{array}$ & 2 \\
\hline 4 & $\begin{array}{l}\text { Perusahaan tekstil dan garmen yang baru IPO } \\
\text { (BELL) }\end{array}$ & 1 \\
\hline 5 & Jumlah & 10 \\
\hline
\end{tabular}

Tabel dibawah ini adalah daftar sampel perusahaan yang akan diteliti dan telah memenuhi kriteria diatas:

Tabel 2

Sampel Perusahaan Tekstil dan Garmen

\begin{tabular}{|l|l|l|}
\hline No & Kode & Nama Perusahaan \\
\hline 1 & ARGO & Argo Pantes Tbk \\
\hline 2 & RICY & Century Tekstile Industry Tbk \\
\hline 3 & ERTX & Eratex Djaya Tbk \\
\hline 4 & ESTI & Ever Shine Tex Tbk \\
\hline 5 & HDTX & Panasia Indo Resource Tbk \\
\hline 6 & INDR & Indo Rama Synthetic Tbk \\
\hline 7 & PBRX & Pan Brother Tbk \\
\hline 8 & POLY & Asia Pasific Fibers Tbk \\
\hline 9 & STAR & Star Petrochem Tbk \\
\hline 10 & TRIS & Trisula Internasional Tbk \\
\hline
\end{tabular}

\section{Metode Analisis Data}

Penelitian ini menggunakan analisis deskriptif kuantitatif dan analisis regresi data panel untuk mengukur Pengaruh variabel independen dan variabel dependen. Doddy Ariefianto (148:2012) data panel adalah jenis data yang merupakan gabungan dari data time series (runtut waktu) dan cross section (seksi silang). Keunggulan dari penggunaan data panel salah satunya adalah dapat memberikan data yang lebih informatif dan lebih baik dalam mendeteksi dan mengatur efek yang tidak dapat diamati dalam data time series dan cross section.

Penelitian ini dilakukan dengan menggunakan alat uji hipotesis multiple regression yang di dalam pengujiannya akan dilakukan dengan bantuan program EViews versi 9.0. Software ini mampu melakukan olah data time series dan panel data. 
Karena kemampuannya melakukan olah data panel, maka eviews mampu menggunakan model fixed effect dan model random effect, sekaligus memilih model mana yang paling tepat melalui uji hausman dan uji chow. Dalam uji-uji statistik terkait data time series, eviews sangat powerfull dalam penggunaannya. Sehingga eviews sangat cocok digunakan untuk olah data times series dan data panel dibidang ilmu ekonomi.

\section{HASIL ANALISIS DATA \\ Pengujian Hipotesis \\ Uji Parsial (Uji T)}

Dari hasil pengujian statistik analisis regresi data panel menggunakan software Eviews, diperoleh hasil sebagai berikut :

Tabel 3

\section{Hasil Uji t-Statistik}

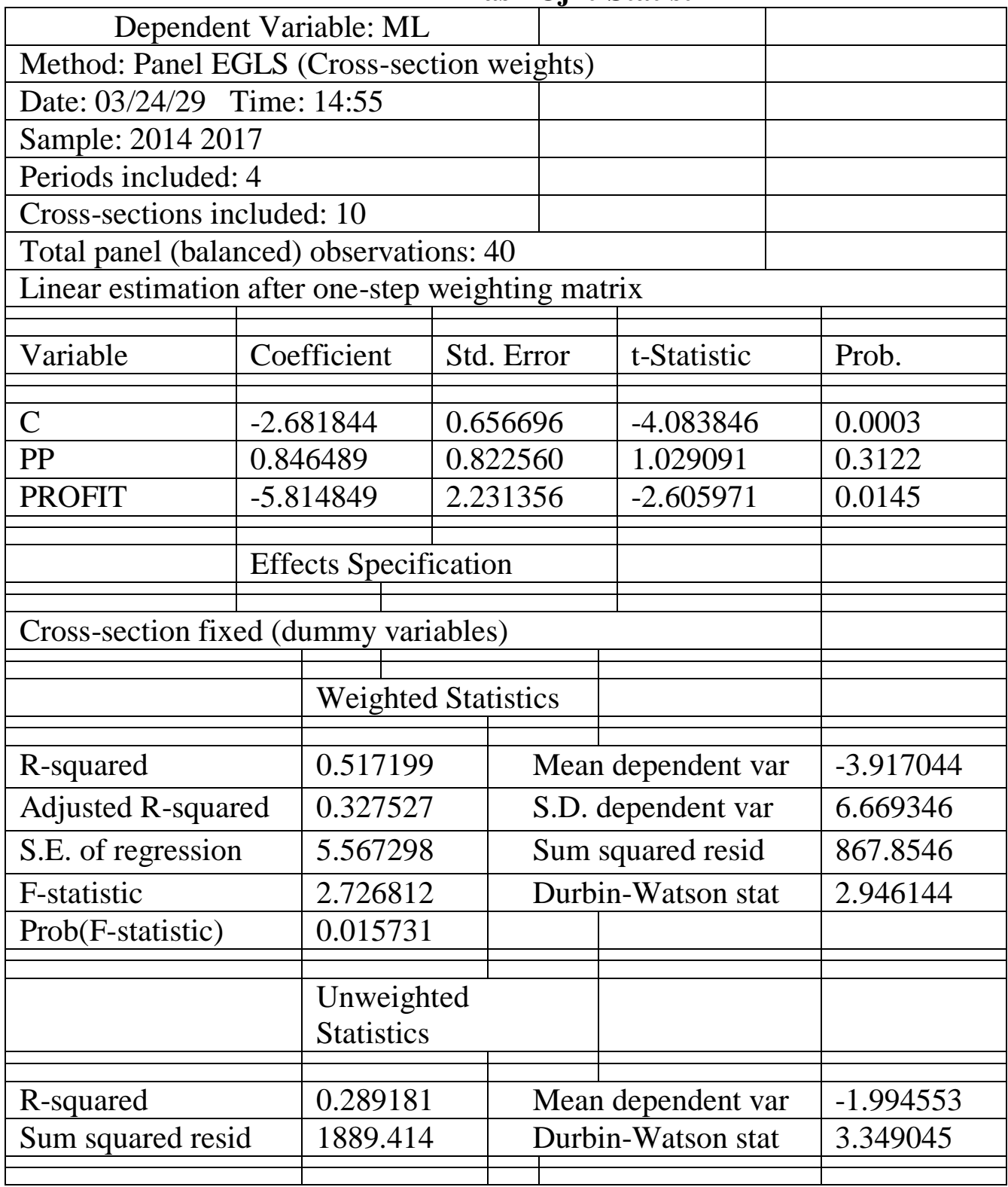

Sumber : Data Olahan Eviews Versi 9 
Berdasarkan hasil analisis regresi data panel pada tabel 3, hasil pengujiannya dapat dimaknai sebagai berikut :

\section{Uji Hipotesis Pertama}

\section{H1: Tidak terdapat pengaruh Perencanaan Pajak terhadap Manajemen Laba}

Pengujian hipotesis pertama dalam penelitian ini adalah untuk menguji apakah Perencanaan Pajak berpengaruh secara signifikan terhadap manajemen laba. Berdasarkan tabel 3 diperoleh hasil estimasi variabel nilai t hitung sebesar $1.029091<\mathrm{t}$ table 2.028 dan probabilitas sebesar 0.3122. Nilai signifikansi lebih rendah dari tingkat signifikansi yang digunakan $(0.3122>0.05)$. Hal ini berarti bahwa variabel perencanaan pajak tidak berpengaruh secara signifikan terhadap pengungkapan manajemen laba.

\section{Uji Hipotesis Kedua}

\section{H2: Terdapat pengaruh signifikan profitabilitas terhadap manajemen laba}

Pengujian hipotesis kedua dalam penelitian ini adalah untuk menguji apakah profitabilitas berpengaruh secara signifikan terhadap manajemen laba. Berdasarkan tabel 3 diperoleh hasil estimasi variabel nilai t hitung sebesar -2.605971>t tabel -2.028 dan probabilitas sebesar 0.0145 . Nilai signifikansi lebih rendah dari tingkat signifikansi yang digunakan $(0.0145<0.05)$. Hal ini berarti bahwa variabel Profitabilitas berpengaruh secara signifikan terhadap manajemen laba.

\section{Uji Simultan (Uji F)}

\section{H3: Perencanaan Pajak, Profitabilitas, berpengaruh terhadap Manajemen Laba}

Hasil uji simultan (uji F) menggunakan Eviews Versi 9 dapat dilihat pada tabel IV.8 sebagai berikut :

Tabel 4

Hasil Analisis Regresi Uji F

\begin{tabular}{|c|c|c|c|c|}
\hline \multicolumn{3}{|c|}{ Dependent Variable: ML } & & \\
\hline \multicolumn{4}{|c|}{ Method: Panel EGLS (Cross-section weights) } & \\
\hline \multicolumn{5}{|c|}{ Date: $03 / 24 / 29$ Time: $14: 55$} \\
\hline \multicolumn{5}{|c|}{ Sample: 20142017} \\
\hline \multicolumn{5}{|c|}{ Periods included: 4} \\
\hline \multicolumn{5}{|c|}{ Cross-sections included: 10} \\
\hline \multicolumn{5}{|c|}{ Total panel (balanced) observations: 40} \\
\hline \multicolumn{5}{|c|}{ Linear estimation after one-step weighting matrix } \\
\hline Variable & Coefficient & Std. Erro & t-Statistic & Prob. \\
\hline $\mathrm{C}$ & -2.681844 & 0.656696 & -4.083846 & 0.0003 \\
\hline $\mathrm{PP}$ & 0.846489 & 0.822560 & 1.029091 & 0.3122 \\
\hline \multirow[t]{2}{*}{ PROFIT } & -5.814849 & 2.231356 & -2.605971 & 0.0145 \\
\hline & Effects Spe & cation & & \\
\hline
\end{tabular}




\begin{tabular}{|c|c|c|c|c|}
\hline \multicolumn{4}{|c|}{ Cross-section fixed (dummy variables) } & \\
\hline & \multicolumn{2}{|c|}{ Weighted Statistics } & & \\
\hline R-squared & 0.517199 & \multicolumn{2}{|c|}{ Mean dependent var } & -3.917044 \\
\hline Adjusted R-squared & 0.327527 & \multicolumn{2}{|c|}{ S.D. dependent var } & 6.669346 \\
\hline S.E. of regression & 5.567298 & \multicolumn{2}{|c|}{ Sum squared resid } & 867.8546 \\
\hline F-statistic & 2.726812 & \multicolumn{2}{|c|}{ Durbin-Watson stat } & 2.946144 \\
\hline \multirow[t]{2}{*}{ Prob(F-statistic) } & 0.015731 & & & \\
\hline & $\begin{array}{l}\text { Unweight } \\
\text { Statistics }\end{array}$ & & & \\
\hline R-squared & 0.289181 & \multicolumn{2}{|c|}{ Mean dependent var } & -1.994553 \\
\hline Sum squared resid & 1889.414 & \multicolumn{2}{|c|}{ Durbin-Watson stat } & 3.349045 \\
\hline
\end{tabular}

Sumber : Data Olahan Eviews versi 9

Berdasarkan tabel 4 pengujian ini dilakukan dengan membandingkan nilai $\mathrm{F}$ hitung ddengan $\mathrm{F}$ tabel apabila $\mathrm{F}$ hitung $>\mathrm{F}$ tabel dengan signifikansi dibawah 5\% $(0,05)$ maka secara bersama-sama (simultan) variabel bebas berpengaruh signifikan terhadap variabel terikat, begitu juga sebaliknya. Berdasarkan hasil uji simultan pada tabel 4 diatas diperoleh $F$ hitung 2.726812> F tabel 2.25 sehingga seluruh variabel terikat bebas secara bersama-sama merupakan penjelasan yang signifikan terhadap variabel terikat dan dengan tingkat signifikan0.015731<0.05.hal ini sesuai dengan syarat diatas yang berarti hipotesis yang menyatakan bahwa secara simultan variabel bebas (Perencanaan Pajak dan Profitabilitas) berpengaruh secara signifikan terhadap Manajemen Laba pada perusahaan tekstil dan garmen yang terdaftar di Bursa Efek Indonesia.

\section{Uji Koefisien Determinasi $\left(\mathbf{R}^{2}\right)$}

Tabel 5

Uji Koefisien Determinasi $\left(\mathbf{R}^{2}\right)$

\begin{tabular}{|l|l|l|l|l|}
\hline & \multicolumn{2}{|l|}{ Weighted Statistics } & & \\
\hline \hline R-squared & 0.517199 & \multicolumn{2}{|l|}{ Mean dependent var } & -3.917044 \\
\hline Adjusted R-squared & 0.327527 & \multicolumn{2}{|l|}{ S.D. dependent var } & 6.669346 \\
\hline S.E. of regression & 5.567298 & \multicolumn{2}{|l|}{ Sum squared resid } & 867.8546 \\
\hline F-statistic & 2.726812 & \multicolumn{2}{|c|}{ Durbin-Watson stat } & 2.946144 \\
\hline Prob(F-statistic) & 0.015731 & & & \\
\hline \hline & $\begin{array}{l}\text { Unweighted } \\
\text { Statistics }\end{array}$ & & \\
\hline & & & & \\
\hline
\end{tabular}




\begin{tabular}{|l|l|l|l|}
\hline R-squared & 0.289181 & Mean dependent var & -1.994553 \\
\hline Sum squared resid & 1889.414 & Durbin-Watson stat & 3.349045 \\
\hline \hline
\end{tabular}

Sumber : Data Olahan Eviews versi 9

Koefisien Determinasi $\left(\mathbf{R}^{2}\right)$ menggambarkan seberapa besar variabel independen secara bersama-sama (Perencanaan Pajak dan Profitabilitas) dapat menjelaskan variabel dependennya (Manajemen Laba). Berikut hasil pengolahan data dengan Eviews 9, maka diperoleh sebagai berikut :

Berdasarkan tabel diatas diperoleh R Square $\left(\mathbf{R}^{\mathbf{2}}\right)$ sebesar 0.517199, berarti bahwa sebesar 51.71\% Manajemen Laba dijelaskan oleh variabel Perencanaan Pajak dan Profitabilitas. Sedangkan sisanya $48.29 \%$ dijelaskan oleh variabel lain diluar model. Hasil dari olah data menunjukkan bahwa sumbangan variabel Perencanaan Pajak dan Profitabilitas dalam menjelaskan Manajemen Laba berpengaruh besar, dan ternyata sumbangan dari faktor lain yang tidak dimasukkan dalam model regresi panel mempunyai relatif kecil terhadap Manajemen Laba.

\section{Interprestasi Hasil}

Berdasarkan hasil pengujian dari masing-masing variabel secara parsial dapat dijelaskan sebagai berikut :

\section{Pengaruh perencanaan pajak terhadap manajemen laba}

Perencanaan Pajak perusahaan untuk menunjukkan perusahaan yang agresif terhadap pajak dengan melihat informasi tambahan terkait Manajemen Laba.Variabel ini digunakan untuk menguji apakah agresivitas pajak mempengaruhi secara signifikan terhadap pengungkapan tanggung jawab sosial perusahaan.variabel nilai t hitung sebesar $1.029091<\mathrm{t}$ table 2.028 dan Perencanaan Pajak sebesar 0.3122. nilai signifikansi lebih rendah dari tingkat signifikansi yang digunakan $(0.3122>0.05)$. Hal ini berarti bahwa variabel perencanaan pajak tidak berpengaruh secara signifikan terhadap pengungkapan manajemen laba.

Perencanaan pajak merupakan langkah awal dalam manajemen pajak.Karena pihak manajemen menginginkan beban pajak seminimal mungkin maka perusahaan melakukan perencanaan pajak. Pada tahap ini dilakukan pengumpulan dan penelitian terhadap peraturan perpajakan agar dapat diseleksi jenis tindakan penghematan pajak yang akan dilakukan.

Penelitian Fadhlizen, Meihendri dan Darmayanti (2013) yang meneliti tantang pengaruh perencanaan pajak terhadap manajemen laba pada perusahaan manufaktur yang terdaftar di Bursa Efek Indonesia juga menunjukkan hasil bahwa perencanaan pajak tidak berpengaruh secara signifikan terhadap manajemen laba.

\section{Pengaruh profitabilitas terhadap manajemen laba}

Rasio profitabilitas adalah rasio yang digunakan untuk mengukur seberapa efektif perusahaan beroperasi sehingga menghasilkan keuntungan bagi perusahaan. hasil estimasi variabel nilai $\mathrm{t}$ hitung sebesar -2.605971> t tabel -2.028 dan probabilitas sebesar 0.0145. nilai signifikansi lebih rendah dari tingkat signifikansi yang digunakan $(0.0145<0.05)$. Hal ini berarti bahwa variabel Profitabilitas berpengaruh secara signifikan terhadap manajemen laba.

Profitabilitas merupakan suatu indikator kinerja manajemen dalam mengelola kekayaan perusahaan. Profitabilitas menunjukkan kemampuan manajemen dalam 
menghasilkan laba dengan memanfaatkan aktiva yang digunakan dalam kegiatan operasi. Perusahaan yang memperoleh laba yang besar akan tetap mempertahankan labanya karena untuk memberikan dampak kepercayaan terhadap investor agar mau berinvestasi pada perusahaan yang dikelolanya.

Sementara, berdasarkan hasil pengolahan data eviews 9 secara simultan, dapat disimpulkan bahwa terdapat pengaruh antara Perencanaan Pajak dan Profitabilitas pada perusahaan tekstil dan garmen yang terdaftar di Bursa Efek Indonesia tahun 2014-2017. F hitung 2.726812> F tabel 2.25 sehingga seluruh variabel terikat bebas secara bersamasama merupakan penjelasan yang signifikan terhadap variabel terikat dan dengan tingkat signifikan0.015731< 0.05.hal ini sesuai dengan syarat diatas yang berarti hipotesis yang menyatakan bahwa secara simultan variabel bebas (Perencanaan Pajak dan Profitabilitas) berpengaruh secara signifikan terhadap Manajemen Laba pada perusahaan tekstil dan garmen yang terdaftar di Bursa Efek Indonesia.

\section{PENUTUP}

\section{Kesimpulan}

Dari analisis sampel data yang menggunakan Eviews 9, pengujian hipotesis, dan pembahasan, maka ditarik kesimpulan dari penelitian ini sebagai berikut :

1. Berdasarkan pengujian hipotesis pertama dalam penelitian ini adalah untuk menguji perencanaan pajak tidak berpengaruh terhadap manajemen laba. variabel nilai t hitung sebesar $1.029091<\mathrm{t}$ table 2.028 dan probabilitas sebesar 0.3122. nilai signifikansi lebih rendah dari tingkat signifikansi yang digunakan (0.3122>0.05). Hal ini berarti bahwa variabel perencanaan pajak tidak berpengaruh secara signifikan terhadap pengungkapan manajemen laba.

2. Berdasarkan pengujian hipotesis kedua dalam penelitian ini adalah untuk menguji apakah profitabilitas berpengaruh terhadapmanajemenlaba.. $\mathrm{t}$ hitung sebesar -2.605971> t tabel -2.028 dan probabilitas sebesar 0.0145. nilai signifikansi lebih rendah dari tingkat signifikansi yang digunakan $(0.0145<0.05)$. Hal ini berarti bahwa variabel Profitabilitas berpengaruh secara signifikan terhadap manajemen laba.

3. Uji F yaitunilaihitung 2.726812> F tabel 2.25 sehingga seluruh variabel terikat bebas secara bersama-sama merupakan penjelasan yang signifikan terhadap variabel terikat dan dengan tingkat signifikan $0.015731<0.05$.

\section{Saran}

Berdasarkan keterbatasan penelitian yang telah diungkapkan, maka diberikan saran untuk penelitian selanjutnya yaitu :

1. Penelitian selanjutnya dapat menambah variabel independen yang terkait dengan Manajemen Laba seperti tipe idustri, umur perusahaan, nilaiperusahaan, beban pajak tanguhan dan lain-lain. Penelitian selanjutnya memperbanyak ukuran sampel, 
memperpanjang periode pengamatan sehingga pengaruh dapat dilihat dari banyaknya uji empiris dan juga menggunakan objek penelitian yang lebih luas, tidak hanya pada perusahaan tekstil dan garmen yang terdaftar di Bursa Efek Indonesia tetapi juga ditambah dengan perusahaan perusahan luar negeri yang melakukanmanajemenlaba, karena semakin lama interval waktu dan semakin banyak sampel pengamatan maka semakin besar kesempatan untuk memperoleh informasi tentang variabel yang handal untuk melakukan peramalan yang lebih akurat.

2. Pada saat penelitian, mungkin melewatkan beberapa informasi didalam laporan tahunan perusahaan sampel yang seharusnya ikut dimasukkan dalam perhitungan manajemen laba.

\section{DAFTAR PUSTAKA}

Ariefianto, Moch. Doddy. 2012. Ekonometrika esensi dan aplikasi dengan menggunakan EViews. Jakarta: ERLANGGA

Astuti, Fransisca Dewi. 2011. Pengaruh Asimetri Informasi, Ukuran Perusahaan dan Leverage Terhadap Praktik Manajemen Laba.Skripsi. Universitas Sanata Dharma, Yogyakarta.

Damayanti, Theresia. 2008. Perbandingan Akrual dan Pajak Tangguhan dalam Pengujian Aliran Kas Masa Datang dan Return Saham. Jurnal akuntansi.

Lukman, Dendawijaya. 2009. Manajemen Perbankan. Jakarta: Ghalia Indonesia

Djamaluddin, Subekti. 2008. Analisis Perbedaan antara Laba Akuntansi dan Laba Fiskal Terhadap Persistensi Laba, Akrual, dan Aliran Kas Pada perusahaan Perbankan yang Terdaftar di Bursa Efek Jakarta. Jurnal akuntansi

Ghozali, Imam. 2007. Aplikasi Analisis Multivariate dengan Program SPSS adan Penerbit Universitas Diponegoro, Semarang

Guna, Welvin I, Arleen Herawaty. 2010. Pengaruh Mekanisme Good Corporate Governance, Independensi Auditor, Kualitas Audit Dan Faktor Lainnya Terhadap Manajemen Laba. Jurnal Bisnis dan Akuntansi

Hasni, Nurul. 2013. Pengaruh Aktiva Pajak Tangguhan dan Ukuran Perusahaan dan Probabilitas Perusahaan melakukan Manajemen Laba pada Perusahaan Manifaktur yang terdaftar di BEI. Skripsi UPI YPTK Padang 
Indri. 2011. Analisis Pengaruh Mekanisme Good Corporate Governance, Profitabilitas dan Leverage terhadap Manajemen Laba. Skripsi: Universitas Diponegoro

Mardiasmo. 2011. Perpajakan Edisi Revisi. Yogyakarta: Penerbit Andi. 2011

Pohan, Chairil Anwar. (2013). Manajemen Perpajakan Strategi Perencanaan Pajak dan Bisnis. Gramedia Pustaka Utama. Jakarta

Scott, William R. 2015. Financial Acounting Theory. $6^{\text {th }}$ ed. Toronto :Pearson Education $\mathrm{C}$ anada, Inc.

Sulistiawan Dedhy, Yeni Januarsi, dan liza Alvia. 2011. "Creative Accounting: Mengungkap Manajemen Laba dan Skanda lAkuntansi'’Salemba Empat, Jakarta.

Ulfa, Yana. 2012. Pengaruh Beban Pajak Tangguhan dan Perencanaan Pajak Terhadap Manajemen Laba. Simposium Nasional Perpajakan 4.

Zain, Mohammad. 2005. Manajemen Perpajakan. Bandung. Program Pascasarjana. UNPAD

www.Kemenperin.go.id

www.idx.co.id

www.pajak.go.id

www.unisosdem.org 
Majalah Ilmiah Solusi

Vol. 17, No. 4 Oktober 2019

ISSN : 1412-5331

Halaman ini sengaja dikosongkan 